MARCO TIBALDINI

Free University of Bozen-Bolzano

\title{
Talus: Etymology of a Ludonym and how the Names of an Ancient Gaming Practice could be Indicative of Processes of Cultural Transmission and Stratification
}

This paper presents the complex history of the names given to knucklebones by different ancient civilizations. During the whole of antiquity these particular gaming tools had precise cultural and symbolical connotations, which influenced their gaming use and crossed many social, chronological, geographical and cultural boundaries.

The peculiar role played by knucklebones within human gaming practices stretches across several millennia. In western Europe during the early Middle Ages, their use went into decline in favour of cubic dice. Over the centuries scholarship has overlapped and confounded the terminology relating to these two different gaming traditions, causing many misunderstandings and translation issues.

However, thanks to advances in the field of game studies and through the examination of literary, iconographic and archaeological data, it is possible to establish the original names given to games using astragals and also the complex signifiers and implications that they had for classical culture. ${ }^{1}$

Keywords: talus, talis ludere, knucklebones, astragals, kișallu, Latin etymology, ancient games, translation issues

\section{Why study ancient board games?}

In ancient times board games were objects of daily use and the interpersonal and interactional nature of play could easily turn board, dice and counters into tools that served as lubricant for social interactions. ${ }^{2}$

\footnotetext{
${ }^{1}$ I thank Robert Houghton (University of Winchester), Helen V. Forsyth (University of Bolzano), Stephen Kidd (Brown University) and Walter Crist (Maastricht University), Christopher Dobbs (University of Missouri), Michael Loss (Thomson Reuters), Eddie Duggan (University of Suffolk) for reviewing this paper.

2 CRIST-De VOOGT-DunN-VATURI (2016).
} 
This could take place internally within a community, facilitating the relations between people of different ages or social positions, but also externally, creating occasions for cross-cultural communications.

This structural aspect of play could easily lead to the stratification of gaming practices into a cultural context, or trigger processes of intercultural exchanges and transmissions, and subsequently of indigenization or cultural appropriation.

In fact, ancient board games preserved the memory of all these processes and any of their aspects could be interpreted and analysed as a trace of a historical process. For this reason, studying ancient gaming traditions allows a better understanding of ancient societies, but also of the medium and long-term historical processes in which they took part, like transcultural exchanges, social evolutions and cultural stratifications.

\section{Material and immaterial evidence}

Any game consists of a material part - the board and gaming pieces, and an immaterial one - the set of rules and the socio-cultural implications of its use, propriety or distribution. Sometimes the permanence or the modification of the material morphology of a game could be indicative of its historical, social or cultural implication, while at other times this complexity could be detected just after the recognition of a continuity/discontinuity occurring on the immaterial side.

\section{Board games, their names and their terminology}

Ludonyms, the names given for centuries to board games and their components, are part of the immaterial legacy preserved by board games, and their linguistic and philological analysis could be extremely useful in bringing to light some of the processes of cultural transmission and stratification.

Being aware of the etymology, or historical complexity, of a Greek or Roman word allows a classical philologist to achieve a higher level of comprehension of an ancient text, and subsequently to derive better translations, commentaries, or footnotes. The terminology related to gaming practices does not constitute an exception to this rule.

Unfortunately, a sort of cultural stigma surrounds gaming activity, which until recently was considered culturally and historically irrelevant. Since the Renaissance, only a few scholars, and not the most quoted ones, 
conducted in-depth studies into ancient gaming practices, and their perspective never filtered into the Greek and Latin vocabularies, with the result that today many of the translations or comments besides certain literary passages related to games are wrong, inaccurate, simplified or anachronistic.

The reader could easily test this statement by browsing a critical edition of Plato's Republic, ${ }^{3}$ or Aristotle's Politics, ${ }^{4}$ where references will typically be found to Chess, Chessboard, Draughts - games which emerged during the Middle Ages and were unknown in the ancient world - and the word dice is used flexibly to indicate any casting object.

The footnotes ${ }^{5}$ of this paper detail some samples of this inaccuracy, highlighting the translation issues in texts distributed over more than two centuries and which relate to different disciplinary areas, to show how this cultural bias affecting scholarly conceptions of gaming practices is crosscultural, cross-generational, cross-disciplinary and, above all, still present.

So, the purpose of this paper is twofold: to show how complex the history of a ludonym could be, and to demonstrate not just philologists, but also historians, sociologists, and even just interested non-academics, the importance of understanding this complexity.

\section{The sample of Knucklebones: a simple gaming tool, a complex history, a forgotten ludonym}

Among the most interesting gaming tools used in antiquity are knucklebones. Their history, their linguistic implications and finally their partial disappearance, could be indicative of the importance of reconstructing the cultural background of a ludonym and fully rehabilitating it.

Knucklebones are bones situated in the posterior legs of quadrupeds and in antiquity, prevalently those of the ovicaprids, were the most appreciated among all the gaming tools.

An approximative calculation of the material evidence found on archaeological sites can help to understand how popular they were among the Greeks and Romans: in 2018 the findings of cubic dice counted around 1,200 artefacts, compared to 36,700 knucklebones. ${ }^{6}$

\footnotetext{
${ }^{3}$ Plat. Rep., 333b; 347c; 422d-e; 487c-d; 522c-d; 536e-537a; 604b-c; 459.

4 Aristot. Pol., 1253a.

${ }^{5}$ Notes $15 ; 44 ; 55 ; 66 ; 112$.

${ }^{6}$ KÜCHELMANN (2017/2018: 109-133).
} 
Their first appearance dates to the Neolithic Period, ${ }^{7}$ and knucklebones of any kind (natural, artificial, painted, vases in shape of knucklebones, weights in shape of knucklebones) are continuously attested in various regions of the Mediterranean until late antiquity.

In Anatolia, as in other regions in the Near East, they are still in use ${ }^{8,}$ while their use as randomizing elements disappeared, or became less relevant, a long time ago from the cultural tradition of western Europe.

For this reason, their presence in ancient literature passed unnoticed by the majority of the European humanists and philologists, which conflated their concept and terminology with another gaming tool whose use was similar: the cubic dice. Once this simplification was unconsciously accepted by philologists, it led many scholars to translate terms related to knucklebones simply as 'dice', with the result of weakening, simplifying or even erasing the connection of this gaming practice with its cultural, linguistic and historical background.

\section{Knucklebones and their ludonyms in the Bronze Age}

In the Sumerian language knucklebones were called zi.in.gi, while $z i$-ingi gir-ra-ra meant the act to play with them. In Akkadian they were called kișalli (a term from which eventually derived similar words in other Semitic languages like Hebrew karșullayim and the Syriac kurșlā). ${ }^{10}$

This can be derived from a bilingual tablet of the $1^{\text {st }}$ century BC found in the Mesopotamian site of Erech, but surely copied from a more ancient one and part of a longer composition originally made up of 5 tablets. ${ }^{11}$

\footnotetext{
${ }^{7}$ HADDOW (2015: 54; 102; 253).

${ }^{8}$ AND (1979: 59).

${ }^{9}$ Concerning the translation of the Akkadian term kișallu as 'knucklebone', LANDSBERGER (1960: 121; 126; 127).

10 SED I No. 169, KoGAN (2011: 225).

11 The text is the Late Bilingual Exaltation of Ištar. A quick bibliography related to it and to its ancient tablets: HRUŠKA (1960: 473-522); LANGDON (1919: 73-84); THUREAUDANGIN (1914: 141-158); FALKENSTEIN (1952: 88-92); LAMBERT (1971: 91-95); LANGDON (1923: 12); ZGOLL (1997).
}

Ancient tablets:

$\begin{array}{lll}\text { W 22729,2 } & \text { Pub. SBTU 2, 28 } & \text { CDLI P348633 } \\ \text { AO 6458 } & \text { Pub. TCL 6, 51 } & \text { CDLI P363723 } \\ \text { AO 6493 } & \text { Pub. TCL 6,52 } & \text { CDLI P363724 }\end{array}$


This text alternates lines written in Sumerian with their Akkadian translation:

May the arrowhead that pierces lungs and heart go back and forth like a shuttle.

O Inanna, ${ }^{12}$ make fight and combat ebb and flow ${ }^{13}$ like a skipping rope;

O lady of battle, make the fray clash together like the pukku and mekk $\hat{u}$

O goddess of contention, make battle be pursued like counters ${ }^{14}$ being manipulated

Lady, at the place of clashing of weapons, strike with chaos like the banging down of knucklebones. ${ }^{15}$

\begin{tabular}{lll}
\hline VAT 14488 & Pub. LKU 12 & CDLI P414154 \\
VAT ---- & Pub. LKU 135, p.27 & CDLI P414266 \\
VAT 16439a+b & Pub. VS 24, 37 & CDLI P347156 \\
Bod S 302 & RA 12, 73-84 & CDLI P368468 \\
K 13459 & Hruška, p. 522 & CDLI P357130 \\
K 15340 & unpublished & CDLI P357423 \\
80-7-19, 281 & unpublished & CDLI P452027
\end{tabular}

I thank Pr. D. A. Foxvog for sharing this information.

12 In Akkadian, the goddess Ištar.

${ }^{13}$ Literarily: "bend back".

14 Or also: "of puppets/dolls".

15 Tablet BodS 302, Bodleian collection, frontside, lines 1-5:

geš ${ }_{\text {kak mur ša }}$-ga an-da-ab-la ${ }_{2}-\mathrm{am}_{3}$ bar-bar-re-eš he ${ }_{2}$-en-

$\mathrm{su}_{3}-s u_{3} u_{2}$-ș mu-šaq-qir lib $3_{3}$-bi u ha $a$-še-e ki-i $u_{2}$-ki-i liš-ta-ad-di-ih

$\mathrm{d}_{\text {inanna ti-sah }}$ geš-la $_{2}$ ešemen 2 -gin $7 \mathrm{u}_{3}$-mi-ib 2 -SAR-SAR

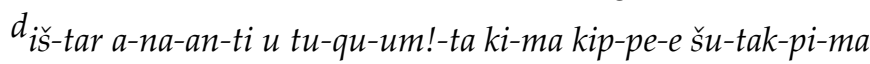

e-lag geš ellag geš-du ${ }_{3}$-a-gin 7 nin me $_{3}$-a teš ${ }_{2}$-a-ra se $_{3}$-se ${ }_{3}$-ga-ba-ni-ib 2

ki-ma pu-uk-ku u $u_{3}$ mi-ik-ke-e be-let ta-ha-zi šu-tam-ḩi-șu tam-h̆a-ru

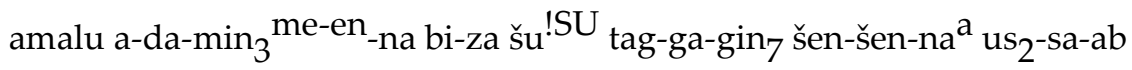

i-lat te-șe-e-ti ki-ma me-lul-tu 2 pa-as-si re-de-e qab-lu

$\mathrm{d}_{\text {in-nin ki }}$ geš tukul sag $_{3}$-ga zi-in-gi ra-ra-da-gin 7 igi-suh ${ }_{3}$-sah ${ }_{4}$ ra-ra-ab

_ $d_{\text {min_a-šar tam-hu-uṣ kak-ku u dab }}$-de-e ki-ma ki-șal-la me ${ }_{2}$-li-li sah-maš-tu 2

First transliteration: LANGDON (1915: 73-84). The present translation comes from a comparison between: CASTELLINO (1977); HRUŠKA (1960: 473-522); LAMBERT (1971: 91- 
Notably, in the Mesopotamian context, Inanna/Ištar, goddess of fertility but also of war, was strongly connected to games ${ }^{16}$ and some scholars suggest that for the terrifying goddess of war 'the fierce battle is enjoyable like a dance or game'. ${ }^{17}$

Another bilingual tablet, partially corrupted, reports:

Play with gaming pieces;

playing with knucklebones ${ }^{18}$

Unfortunately, the corrupted section is exactly the Akkadian translation of this last line, which is comprehensible only thanks to its Sumerian counterpart, where it is possible to read zi-in-gi gir-ra-ra.

Interestingly this Sumerian line is followed by an unexpected Akkadian translation which doesn't mention the word kișallu but a term whose root is $t a-:$ MIN šá $t a-x-x$.

The Assyriologist Irving Finkel suggests that: "one way to harmonize these would be to read MIN šá ta-la-[an-ni], var. šá [da (?)] lá-an". ${ }^{19}$

Thanks to the corresponding Sumerian line, one should assume that this word talañu / talannu / dalan is a synonym of kișallu and equally means 'knucklebone'.

Finkel adds another piece of evidence to support his reconstruction. The Amarna letter EA 22, dating back to the Bronze Age and sent by Tushratta, king of Mitanni, to the Egyptian pharaoh, reports a list of royal gifts in which figure also:

Two alabaster telannu, five golden dogs of five shekels each, five silver dogs of five shekels each. ${ }^{20}$

95). Emendate according to FINKEL (2007) and VERMAAK (2011). Interestingly, CASTELLINO translated ki-șal-la as "play with dice" ("come nel gioco dei dadi").

${ }^{16}$ LANGDON (1915: 73-84); GENOUILLAC (1913: 69-80); KILMER (1982); KILMER (1991: 922); GRONEBERG (1987: 115-124); LANDSBERGER (1960: 109-129); DUCHESNE-GUILLEMIN (1983:151-156); VERMAAK (2011: 112); ANNUS-SARV (2015: 285-286).

17 ANNUS-SARV (2015: 285).

${ }^{18}$ Antagal F 245-46 (MSL 17), CT 19, pl. 30-32, K 04352+, r ii 20: Play with gaming pieces: giš-bi-za-šu-tag-ga = MIN (= melulu) šá pa-si; Play with astragals: zi-in-gi gir-ra-ra= MIN šá ta-x-x.

${ }^{19}$ FINKEL (2007: 29). 
Suitably, Finkel considers that this passage is referring to a board game and these two alabaster telannu were indeed knucklebones.

In fact, the term 'dogs' was used in Bronze Age Mesopotamia, ${ }^{21}$ but also later by the Jews ${ }^{22}$ and Greeks, ${ }^{23}$ to indicate gaming pieces. Also, one of the most popular board games in the Near East during the Bronze Age was the Game of 20 Squares, ${ }^{24}$ which, according to a Babylonian tablet now exhibited at the British Museum, was played with two sets of five counters each ${ }^{25}$ and two knucklebones:

An ox knucklebone, a sheep knucklebone,

Two move the pieces. ${ }^{26}$

This statement finds some confirmation in the archaeological evidence, since knucklebones emerged from the archaeological sites of the Bronze Age, or appear in the contemporary iconography, often in pairs. ${ }^{27}$

Generally, those couples consist of two ovicaprid knucklebones, implying that probably they were thrown together, and their result was given by a special combination of sides or by the sum of the arithmetical

${ }^{20}$ EA 22, col IV, lines 7-9, in KNUDZTON (1915: 174).

${ }^{21}$ FINKEL (1993: 64-72). Tablet DLB, Colophon, left edge:

1 KASKAL.KUR UR.[GI7.] MEŠ šá šu-ur-ru-h[u .......]

2 NU SAR.MEŠ mi-lul-ti NUN.MEŠ[....] (FINKEL 2007: 28)

22 Babylonian Talmud, Kethuboth, fol. 61b.8; Commentary on the Babylonian Talmud (Qiddušin fol. 21b) by Rabbi Hananel Ben Hushiel.

${ }^{23}$ It was usual for the Greeks to refer to gaming pieces as dogs. A sample could be

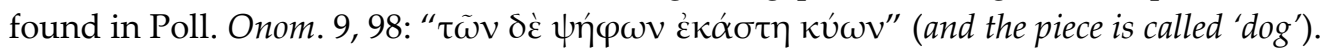

${ }^{24}$ For an updated overview about this game and its distribution: CRIST-DUNN-VATURIDE VoOGT (2016: 81-101).

${ }_{25}$ Previously catalogued as RM III, 6B, now exposed as BM 33333B, line 6 mention expressly 5 gaming pieces, but in this case representing birds: 5 pa-as-su nap-ru-šu-tu ("Five flying gaming pieces"). FINKEL (2007: 20, 29). https://www.britishmuseum.org/collection/object/W_Rm-III-6-b ${ }^{26}$ BM33333B, line 7-8:

ZI.IN.GI GU 4 ZI.IN.GI UDU NÍTA

2 a-bi-ik pa-as-su. FINKEL (2007: 20, 29).

${ }^{27}$ For depictions of gaming scenes in ancient Egypt: PUSCH (1979: pl.18; 28: 30); PICCIONE (2007: 55-57). Concerning the findings of knucklebones in pairs: LANSING (1917: 26); TAIT (1982: 38-41); QUIBELL (1909: 114); DUNN-VATURI (2012); FRANKFORT-PENDELBURY (1933: 25; pl. 29.2); BASS (1986: 292); CRIST-DUNN-VATURI-DE VOOGT (2016: 9-10). 
values attributed to their sides. Anyway, the Babylonian text just mentioned the use of two different knucklebones, an ox and sheep one, opening up the possibility that each of them had a different mathematical function, influencing the result in different way rather than producing a simple algebraical sum of the single values. ${ }^{28}$

\section{From Mesopotamia to Greece, from kișallu to astragalos:}

The use of knucklebones, probably already as casting objects, ${ }^{29}$ spread to the Balkans during the middle and late Neolithic ${ }^{30}$ and is attested in Greece from at least the Bronze Age. The finding of an undefined quantity of knucklebones is reported in the so-called Palace of Nestor at Pylos, in Messenia, dating back to the late Bronze Age or early Iron Age (1300-1050 BC). ${ }^{31}$

In the Greek language these objects were called $\dot{\alpha} \sigma \tau \varrho \alpha ́ \gamma \alpha \lambda$ เ (astragaloi) and their first mention occurs in the Iliad:

when Menoetius brought me, being yet a little lad, from Opoeis to your country, by reason of grievous man-slaying, on the day when I slew Amphidamus' son in my folly, though I willed it not, in wrath over the astragals. ${ }^{32}$

The etymology of this word is uncertain. Robert Beekes considers the term $\alpha \sigma \tau \varrho \alpha ́ \gamma \gamma \alpha \lambda$ os (astragalos) derived from ỏotćov (ostéon), from which

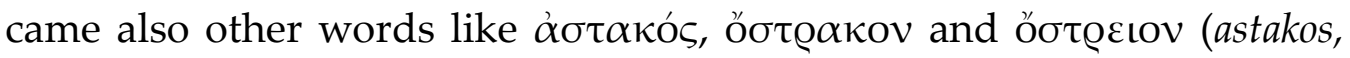
ostracon, ostreion)..$^{33}$

${ }^{28}$ FINKEL (2007: 21-23).

29 SIDÉRA-VORNICU TERNA (2016).

${ }^{30}$ MARCKEVICH (1981); CAVRUC (2005: 333-336); MONAH et al. (2003); KAVRUK et al. (2010: 185); KAVRUK et al. (2013: 128); BELDIMAN-SZTANCS (2010: 143, 15); KOGĂLNICEANU-ILIEMĂRGĂRIT-SIMALCSIK (2014); POPLIN (2001: 31-42); NICA-ZORZOLIU-FANTANEANU-TANASESCU (1977: 10, fig. 3/3a-b); BERCIU (1956: 512); CHOKHADZHIEV-CHOKHADZHIEV (2005: 11); CHOKHADZIEV (2009: 68, fig. 13); URSUlESCU-BOGHIAN (1996: 44); VOINEA-NEAGU (2009); ANDREESCU et al. (2006: 216-218).

31 BLEGEN-RAUSON (1966: 196; 234; 244; 266).

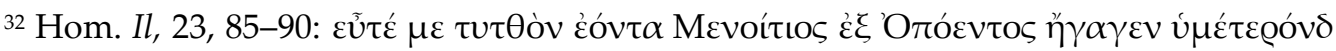

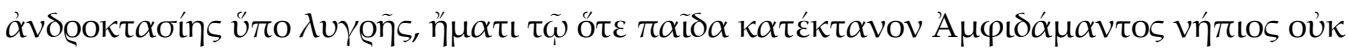

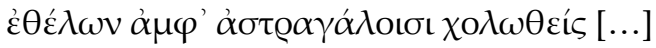

${ }^{33}$ BEEKES (2010: 157-158). 
The etymology proposed by Beekes seems reasonable: even if he didn't specify how the variation in - $g$ - peculiar to the term astragalos and all its derivatives occurred, we find support of this etymology in the lexicon of Hesychius. Here we find one of its synonyms phonetically placed between astragalos and osteon:

Astries: (synonym of) astragals, equivalent of Astrichoi.

Astrichoi: the same. ${ }^{34}$

Even the Lexicon Bachmannianus, a Byzantine text of the $8^{\text {th }}$ or $9^{\text {th }}$ century, reports it:

Astragal: generally used to refer at the vertebras of the neck, or at the game of counters, or also, so is called an herb. ${ }^{35}$

Astragals say the Attics, while in Ionian is also feminine, and also in Homer some occurrences are at the feminine form, like: "the child, even unwilling, got angry because of the astragals".

Pherekrates in his 'The slave teacher': "instead of astragals play with fists!".

Plato in the Lysis: "they played at even and odd". They say also astrichois, like Antiphanes in his Epidaurios: "we played even and odd with 'astrichoi"'

They call the astragals astrichoi, like said the highers. ${ }^{36}$

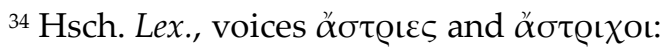

$<\alpha ̋ \sigma \tau \varrho \iota \varepsilon \varsigma>\cdot \alpha \dot{\alpha} \sigma \tau \varrho \alpha ́ \gamma \alpha \lambda$ o (Callim. fr. 276)

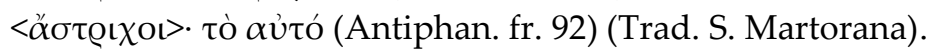

35 Is a plant spread in the whole boreal hemisphere, of whose exists more than 2000 variants (astragalus frigidus, astragalus glycyphyllos, astragalus propinquus, etc.).

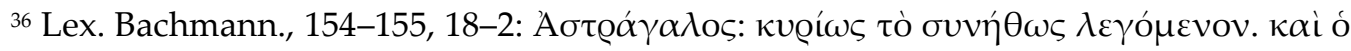

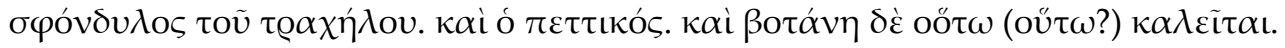

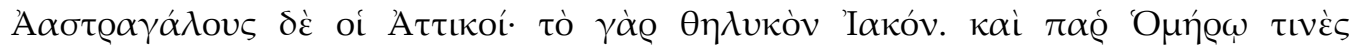
$\theta \eta \lambda v \kappa \tilde{\omega} \varsigma$, oíov

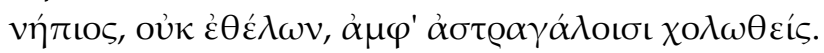

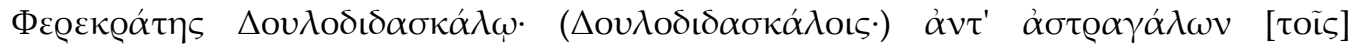

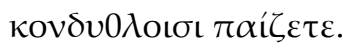

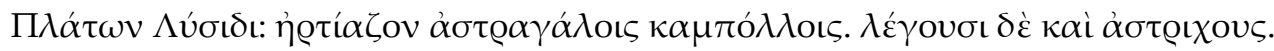

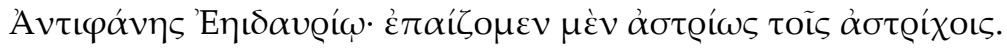

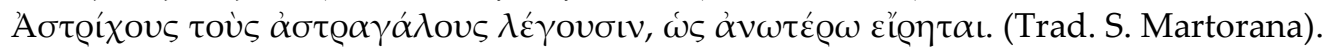


Likewise, a Scholia on Plato states:

Players of astragals:

Astragalizein means to play at astragals, even said astrizein, since the astragals are called also astrias. Callimachus ${ }^{37}$ (wrote) "to you, dear boy, I'll give immediately five astrias of Libyan gazelle just polished". ${ }^{38}$

This quotation of Callimachus informs us about the social prestige of the gazelle's astragals. They were indeed very appreciated, more than the ovicaprids, probably because of their shape and resistance.

Many literary sources ${ }^{39}$ refer to the gazelle astragals using a specific

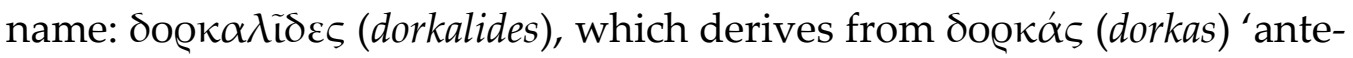
lope'.

During the Classical and Hellenistic period, they were likely quite precious and expensive and only a few of them have been found in the Aegean region. ${ }^{40}$

Some Hellenistic papyri found in Egypt reports gazelle astragals among the goods traded by merchants ${ }^{41}$ and one of the papyri of Zenon of Kaunos, a Greek functionary in Ptolemaic Egypt whose archive has been found in the Faiyum region, reports:

To Zenon, greeting.

If you are well, it would be good. I myself am well. After you sailed out, I brought in the man who cures the astragals made from gazelles' bones, and after examining them he said that they had been extracted

\footnotetext{
${ }^{37}$ Callim. fr. 676 Pfeiffer.

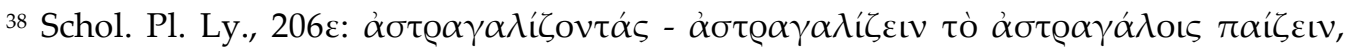

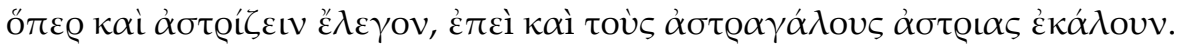

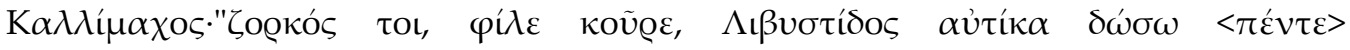

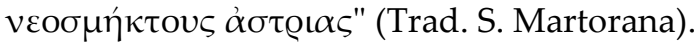

${ }_{39}$ IG II ${ }^{2}$ 1533, 23-24; Athen. 5, 21 (Plb. 26, 1, 8); Callim. fr. 676; Lucian. Am. 15-16; Theophr. Char. 5, 9; Herod. 3, 19, 63.

${ }^{40}$ An astragal of goitered gazelle of Central Asia has been found in the Greco-Roman layers of the Artemision of Ephesus. D.G. HOGART (1908: 192; pl. 36, 42; 36, 43; 14, 3132).

${ }^{41}$ P.Cair.Zen. 1.59019, line 2. Other samples: P. Cair.Zen. 1.59009 fr. B2; P. Cair.Zen. 1.59069,7; PSI 331, 2, 7; PSI IV 444, 2.
} 
from the raw flesh, ${ }^{42}$ and for that reason ... He said therefore they could not be made wax-like, for after a year he said they would change, ${ }^{43}$ but he said that he would make them [passable], but with great trouble he said, so much so that he did not think they were worth it. As for the treatment we shall try to get them done for a chalkous $^{44}$ each, or at most for two chalkoi; for he himself pretends that he does astragals for people at court (?) for half an obol each; and he said we might ask Antipatros the Etesian (?), for he has cured some for him he said. As soon as you receive my letter then, write to me what to do about this before the time runs away. Know too that Patron was not willing to take Apollophanes with him but has given us a great deal of trouble. But I went to see Melas and declared myself ready to be inscribed as a warrantor along with another of the citizens. And he, seeing by this that Apollophanes was not by any means going to be left behind, as we too were fighting against him, took him on board. My further news I will write to you in greater detail than it was possible for me to do now. And try to write to me promptly about everything. Farewell..$^{45}$

\footnotetext{
42 Naturally, astragals are locked by cartilage and tendons. Removing them from the raw flesh would result surely in a troubling activity and would wreck them. To properly extract the astragals is necessary to boil the articulation for several hours to liquify the collagen of the tendons. In that case the astragal emerges by itself, and from this activity results also a very nutritive bone's broth.

${ }^{43}$ The friction of the astragals on a surface would smooth the most exposed surfaces, modifying its shape and weight. A great quantity of smoothed astragals has been found in the archaeological sites, dating to any period, from the late Neolithic till the Roman time.

${ }^{44}$ A copper coin. Is not clear if it refers to the payment for the job, or to the metal to be melt in order to modify the weight of the astragal and correct it. Personally, I consider more suitable the second option, since a great quantity of modified and weighted astragals has been found and even Aristotle use the sample of the cast of a weighted astragal in his Problems, XVI, 913a-913b; 915b.
}

The 20th century Turkish scholar Metin AND (1979: 59) refers that still in the 1970s in Anatolia was usual to hollow some astragals filling them with lead to increase their weight and make them more effective in some kind of game.

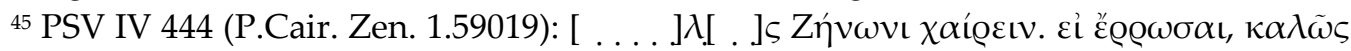

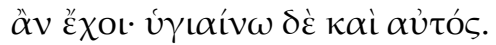

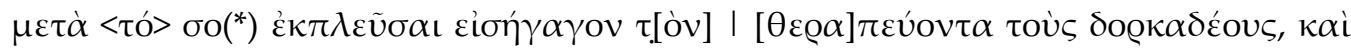

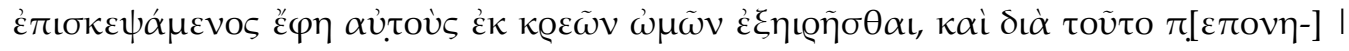


Interestingly, despite the fact that this gaming practice was a longstanding and common tradition shared by the majority of the near eastern civilizations, among all the names given by the Greeks to the knucklebones, none seems to show a process of cultural transmission of oriental origin.

\section{The road to Italy}

It seems that the use of astragals reached the Italian peninsula during the late Bronze Age or early Iron Age and all the most ancient evidence has been excavated along the river Adige, in the northern part of Italy. ${ }^{46}$ This presence should be linked with the 'amber route', a huge network of small-scale trades that crossed the Central Europe during the Bronze Age and reached the Mediterranean. It seems that the trading routes of the period privileged the rivers and one of its main paths passed through the Trentino Valley. ${ }^{47}$ This commercial network was probably multidirectional and as some items travelled from north to south, like Baltic amber, others travelled in the opposite direction. Alongside these materials also circulated ideas, conceptions of the world, traditions, beliefs, superstitions and maybe also gaming practices. Indeed, the pres-

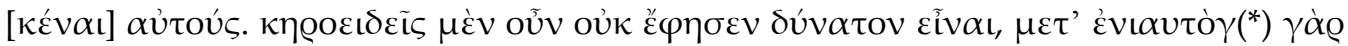

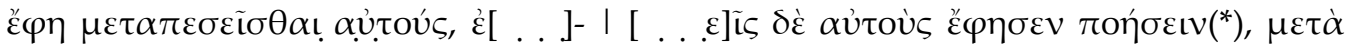

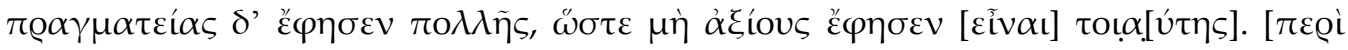

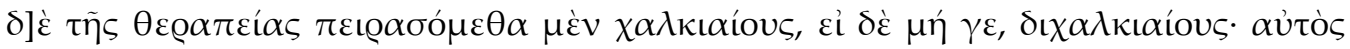

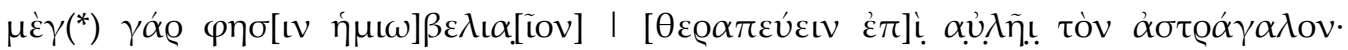

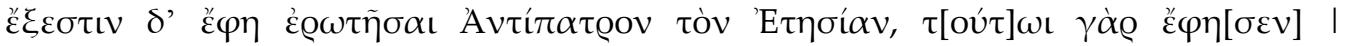

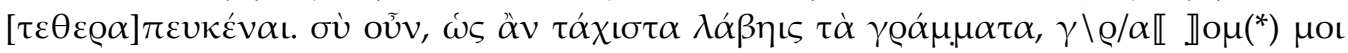

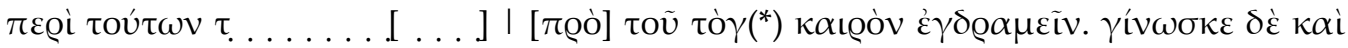

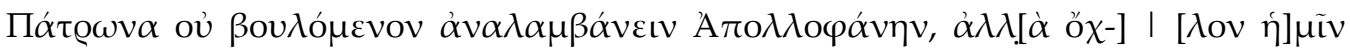

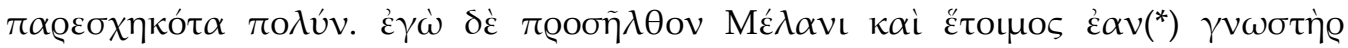

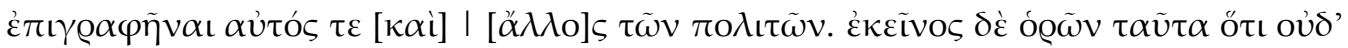

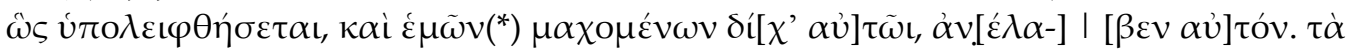

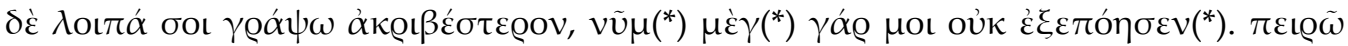

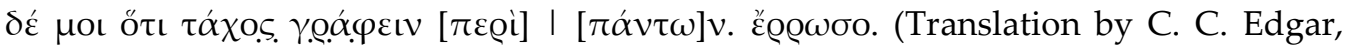
ASAE vol.22, no. 69, emendate) Interestingly, in the original text of C. C. Edgar, all the terms related to astragals were translated as 'dice'.

46 Riedel-Tecchiati (2001); LORENZ (2003); Riedel-TeCCHIATI (2005: 124-125); TECCHIATI (2005); MARCONI-TECCHIATI (2006).

47 DE NAVARRO (1925: 484-485). 
ence of astragals in North-Italian burial sites of the late Bronze Age/early Iron Age attest to a long-haul intercultural exchange.

As far as we know, the first evidence of astragals in central Italy dates to the $6^{\text {th }}$ century BC and attests, once more, to a process of intercultural transmission.

A find in the Etruscan city of Pyrgi consists of a group of 31 astragals altered with holes or other kind of modifications. ${ }^{48}$ The location of this find is quite significant since Pyrgi was a coastal centre that served as commercial hub for the nearby city of Cerveteri and was one of the major ports of the Tyrrhenian Sea.

In one of its temples, which rose aside the shore, the famous Pyrgi Tablets were found: further evidence of intercultural contacts. They consist of three golden tablets with inscriptions in Punic and Etruscan. ${ }^{49}$

Unfortunately, the name given by the Etruscans to the knucklebones is unknown.

\section{Greece and Rome: $\dot{\alpha} \sigma \tau \rho \alpha ́ \gamma \alpha \lambda o \iota$ and TALI}

In January 1899 the place called lapis niger was identified in the Roman Forum, ${ }^{50}$ and in the following years in the layer dated to the $6^{\text {th }}$ century BC 221 knucklebones were found. ${ }^{51}$ Other contemporary evidence emerged from the area of Sant'Omobono, near the Palatine, within two cultic complexes ${ }^{52}$ and from a bothros, a hypogeal area deputed to funerary rites. ${ }^{53}$

In Latin those objects were called tali, a word which semantically has a perfect correspondence with the Greek astragaloi in indicating the gaming tool as well as the bones from which they were derived. Since ancient times, astragal is also an anatomical term referring to a bone of the human ankle, as stated by Apion: "astragalos signifies three things:

\footnotetext{
48 BAGLIONE (1989-1990).

49 Etruscan Museum of Villa Giulia, Rome, room 13a, cabinet 1, without inventory number. Punic inscription: KAI 277.

${ }^{50}$ BONI (1899).

51 DE GROSSI MAZZORIN-MinNITI (2013: 377).

52 GJeRstAd (1960: 242, fig.154, 1-9).

53 North-eastern side of the Palatine Hill, area II, in DE GROSSI MAZZORIN-MinNITI (2013: 377).
} 
the joint in the ankle, simply any of the vertebrae and the game piece or 'pessos' 54 ". 55

In Latin the same bone was called talus, a term whose meaning was eventually extended to the whole heel, and from which derived several terms in Neo-Latin languages: Tallone (it), Talon (fr), Taló (ct) Talón (sp). It probably also influenced Celtic languages, since the same part of the body in Irish is actually called sál, and sawdl in Welsh. ${ }^{56}$

The first mention of the game of tali in Latin literature is the Miles Gloriosus, where Plautus plays on the double meaning of the word as part of the ankle and gaming objects:

Periplecomenus: (speaking to his servants within). Faith, if you don't in future smash his anklebones (talos) for any stranger that you see on my tiles, ${ }^{57}$ I will cut you so with lashes as to make thongs of your sides. My neighbours, $i^{\prime}$ faith, are overlookers of what is going on in my own house; so often are they peeping down through the 'impluvium'58. And now, therefore, I give you all notice, whatever person of this Captain's household you shall see upon our tiles, except Palaestrio only, push him headlong here into the street. Suppose he says that he is following some hen, or pigeon, or monkey; woe be to you, if you don't badly maul the fellow even to death. And so, that they may commit no infringement against the laws on gambling (lex

54 The term 'pessos' means 'gaming piece', in ancient as well as in modern Greek. Its presence in this quotation of Apion would require a further and deeper discussion, but in complex could point to an eventual unorthodox use of astragals, which means differently than a casting object.

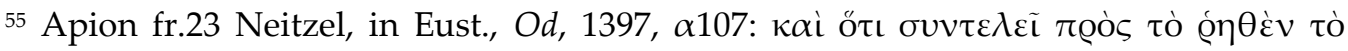

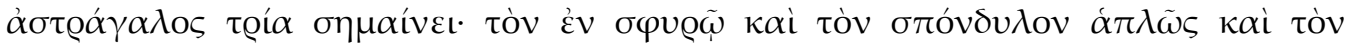

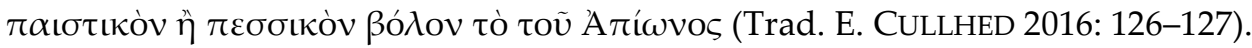

56 ERNOUT-MEILLET (2001: 675).

${ }^{57}$ In this passage Periplecomenus is referring to the roof tiles, where probably seated and walked the undesired tattlers.

${ }^{58}$ In a Roman Domus the impluvium was the sunken part of the central court, designed to carry away the rainwater coming through an opening on the roof called Compluvium. In this passage the term impluvium indicate also the upper opening through which the neighbors looked into Periplecomenus' court. 
alearia), do you take good care that they wouldn't have any anklebones (talis) to shake at the 'convivium'59.60

\section{Aphrodite and Venus, astragaloi and tali, rules and names}

During the Bronze Age, knucklebones were used as randomizing elements for board games and their combinations corresponded to certain numerical values, even if it is not clear which mathematical or algebraical rules this procedure followed. ${ }^{61}$

Among the Greeks, astragals were used as toys (manipulated or thrown by children in riddles, games of aim or manual skill) ${ }^{62}$ and as randomizing tools (thrown mainly by the adults and attempting to produce particular combinations).

The attribution of a numerical value to a certain configuration of the throw is attested in Greece since the Classical period: Diphilus ${ }^{63}$ mentions the Euripides (or more correctly Heurippides) ${ }^{64}$ throw which scored 40 points and Eubulus in his Kubeutai ${ }^{65}$ provides a long list of other throws.

About Eubulus' list of names, Stephen Kidd correctly remarks that: 'none of which is attested elsewhere' and considering that it was part of

\footnotetext{
59 The convivium was a banquet, with festive and joyful connotates, in which the Romans normally played with knucklebones.

60 Plaut. Mil. 2, 2.8-10: Ni hércle diffregéritis talos pósthac quemque in tégulis videritis alienum, ego vostra faciam latera lorea. Mi equidem iam arbitri vicini sunt, meae quid fiat domi, ita per impluvium intro spectant. nunc adeo edico omnibus: quemque a milite hoc videritis hominem in nostris tegulis, extra unum Palaestrionem, huc deturbatote in viam. Quod ille gallinam aut columbam se sectari aut simiam dicat, disperiistis ni usque ad mortem male mulcassitis. Atque adeo ut ne legi fraudem faciant aleariae, adcuratote ut sine talis domi agitent convivium. (Transl. H.T. Riley, emendate) In the original Riley's translation, the expression used to indicate this gaming practice is 'playing dice'.

${ }^{61}$ About the use of astragals applied to the game of 20 squares: FINKEL (2007: 21-23); and to the Senet: PICCIONE (2007: 55-58).

62 A few examples. Such use is reported in classical Greece: Pl., Lys. 206e; Sch. Pl. Lys. 206e (ed. CufAlO, 2007: 182-183); Antiph. fr 92 K.-A.; Ar. Pl. 816-817, 1055-1058; Arist. Rh. 1407b; Cratin. fr. 180 K.-A.; Eup. Fr. 269 K.-A.; Plut. Quaest. Conv. 741c.

${ }^{63}$ Diph. Synoris fr. 47 K.-A. (in Ath. 6, 247a-b). The same information is reported by Poll. 9, 101; Suet. Peri Paid. 1, 22; TAILLARDAT (= $\Sigma$ ad Pl. Lys. 206e $\approx$ Eust. Il. 1289, 55-63).

${ }^{64} \operatorname{KIDD}(2017:$ 113, n. 6).

65 Eub. fr. 57 KA in Poll. 7, 204-205.
} 
a comedy it 'is probably invented out of whole cloth to present an absurd level of connoisseurship'. ${ }^{66}$ But the irony of this alleged exaggeration plays on a real fact, that in the Greece of the fourth and third century $\mathrm{BC}$ it was a common practice to give a name to the throws and scores: a tradition that also passed to the Romans.

The classical authors reported 71 different names of throws (including the long Eubulus' list), ${ }^{67}$ of these, 67 were Greeks and just four Roman, three of which were themselves translations or loanwords from Greek anyway, underlining the process of cultural transmission which conveyed them.

Several Latin sources report the throws of Venus and Canes as the highest and the lowest results, while Plautus alone wrote about a throw called Basilicus (another word of Greek origin) as a positive score, as well as the 'four vultures', the only one which doesn't show any connection with the Greek and that indicated an unlucky score (most probably the lowest possible, eventually similar or identical to the Canes). ${ }^{68}$

After Plautus, several other Roman authors wrote about the game of tali, in reference to both their uses as toys for children ${ }^{69}$ and as randomizing elements for adults ${ }^{70}$ (when astragals or tali were played counting the scores or trying to throw special combinations).

Fortunately, many authors included some indication of the rules of this last typology of game. However, the rules as reported are not always coherent and are sometimes also contradictory.

The Latin authors show a certain continuity throughout the centuries and we have reason to believe that the game remained more or less the same from Plautus' time. The picture given by Greek literature is more complicated since the information reported by Greek authors of the Roman period perfectly match the ones reported by the Latin au-

\footnotetext{
66 KIDD (2017: 114, n. 18); HUNTER, (1983: 142).

${ }^{67}$ An exhaustive list could be found in BECQ DE FOUQUIÈRES (1869: 337-339).

${ }^{68}$ Plaut. Curc. 2, 3, 354-361.

69 i.e. Hor. Sat. 2, 3, 247-253a; Mart. 4, 14; Rufinus of Aquileia, Apologie in Sanctum Hieronimum Libri Duo 2, 22.

70 Some reference other than the ones quoted in the following paragraphs: Plaut. Asin. 771-791; Mart. 14, 15; Ovid. Ars Am. 2, 197-208; 3, 353-384; Ovid. Tr. 2, 475-483.
} 
thors, but presents some incoherence with respect to what can be deduced from the Greek authors of the previous centuries.

In such a complex situation, the names attributed to the different sides of the knucklebones and to their configuration after a throw is crucial for achieving a partial reconstruction of the game rules.

\section{Greeks and Romans: a complex stratification of different gaming traditions}

Persius informs us that the highest score was 6 (dexter senio) while the lowest was 1, called 'dog' (damnosa canicula), ${ }^{71}$ and similarly Martial juxtaposes the senior and canis throw, ${ }^{72}$ but Suetonius, who wrote a whole book about ancient Greek board games, transcribed a letter of Augustus in which it emerged that 6 could also be unfavourable:

And as any one threw upon the tali aces or sixes, he put down for every talus a denarius; all which was gained by him who threw a Venus. ${ }^{73}$

The throw of Venus was the highest possible, even if its numerical value is still unknown (if one had ever been associated with it), and this is an aspect on which all the Greco-Roman sources of the imperial period agree, as is the fact that it resulted when all the knucklebones fell upon a different side:

Tali of Ivory: when no one of the tali will give you the same face, you will tell me that I made you a great gift! ${ }^{74}$

\footnotetext{
71 Pers. 3, 49: [...] quid dexter senio ferret, scire erat in voto, damnosa canicula quantum raderet.

72 Mart. 13, 1.

${ }^{73}$ Suet. Aug. 71: Talis enim iactatis, ut quisque canem aut senionem miserat, in singulos talos singulos denarios in medium conferebat, quos tollebat uniuersos, qui Venerem iecerat. (transl. A. Thomson) Thomson didn't translate the word tali, and Forester in a later edition of this volume glossed: “The Romans, at their feasts, during the intervals of drinking, often played at dice, of which there were two kinds, the tesserae and tali. The former had six sides, like the modern dice; the latter, four oblong sides, for the two ends were not regarded. In playing, they used three tessera and four tali, which were all put into a box wider below than above, and being shaken, were thrown out upon the gamingboard or table." THOMSON-FORESTER (1909: 124).
} 
Despite this convergence, the Venus throw remains a controversial aspect of the game since its first mention in Plautus ${ }^{75}$ and a throw called Aphrodite is not mentioned in Greek until the $2^{\text {nd }}$ or $3^{\text {rd }}$ century AD. ${ }^{76}$

Analysing this fact from a chronological perspective does not help in identifying the origin of this gaming practice or to be certain of the derivation of the Venus throw attested by the Latin authors from a previous Greek tradition, but any way that convergence might have occurred during the imperial era and attests to a standardization of this gaming tradition in the whole Mediterranean region and the process of cultural syncretism that took place during that period.

Four other aspects of the game which recur identically in many sources of the imperial period are the use of 4 astragals, the fact that each of them could fall into 4 positions, the score attributed to them and finally their names too. Pollux, in the $2^{\text {nd }}$ century AD wrote:

The position of the tossed astragal corresponds to a number. The ace is called ' $\operatorname{dog}^{\prime}[\ldots] 2$ and 5, which are on the die, doesn't exist on the astragals. The majority of people say that the 6 is said 'of Koos' while is opposite ' $\operatorname{dog}^{\prime} \cdot{ }^{77}$

And three centuries later, Hesychius still reports the same information:

Koos, Chion: Koos is the astragal which give a 6 . The throw of Chios corresponds to 1 , the one of Koos to $6{ }^{78}$

The scores attributed to the different sides of the knucklebones and the quantity involved in a throw are still problematic aspects, but fortunately the recurrence of the same names, which are attested in Greek litera-

\footnotetext{
${ }^{74}$ Mart. 14, 14: XIV, Tali eborei: Cum steterit nullus vultu tibi talus eodem, Munera me dices magna dedisse tibi.

75 Plaut. Asin. 5, 2, 55.

76 The first mention is in Luc. Erotes 16.

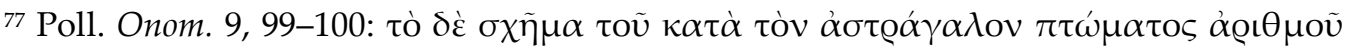

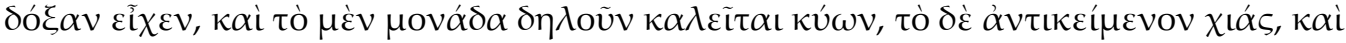

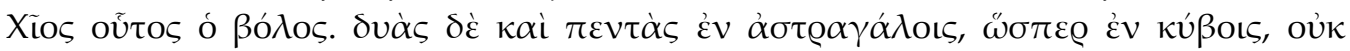

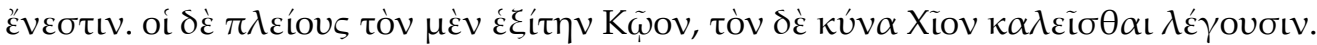

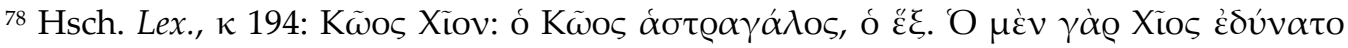

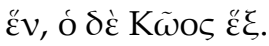


ture from the Classic and Hellenistic period until the late imperial era, could help in the historical reconstruction of this practice. Already Aristophanes makes an allegory on the opposition between Chios and Koos, ${ }^{79}$ and the precise collocation of these two parts of the animal bone is described by Aristotle. ${ }^{80}$ The Anthologia Palatina attributed an epigram to Leonidas of Taras which refers ironically to the fate of a certain Pisistratus playing on the meanings of the word Chios ${ }^{81}$ and another one attributed to Meleager ironizes on Antipater of Sidon in the same way. ${ }^{82}$

The two other controversial aspects, the quantity of astragals used in the games and the scores attributed to each side, remain problematic because of the previously mentioned Euripides throw.

The presence of four astragals recurs in different authors of the Roman period and is confirmed also by the iconography, ${ }^{83}$ but playing with four astragals and getting a 6 on each of them, the sum should logically have been 24 and we cannot compute how the Euripides throw could score $40{ }^{84}$

Considering that a fragment of Callimachus, ${ }^{85}$ previously quoted, mentions a gift of five astragals, and that some Anatolian inscriptions refer to a peculiar divinatory practice based on the throw of five astragals, $^{86}$ Stephen Kidd hypothesized that in Classical and Hellenistic Greece five astragals were used instead of four, and that the best score for each of them was 8 , instead of $6 .{ }^{87}$

He also quotes passages of Pollux ${ }^{88}$ Eustathius, and a Scholion in Plato $^{89}$ which refer to a throw that scored 8 and from which derived the Greek proverb 'all eight' and was named after Stesichorus..$^{90}$

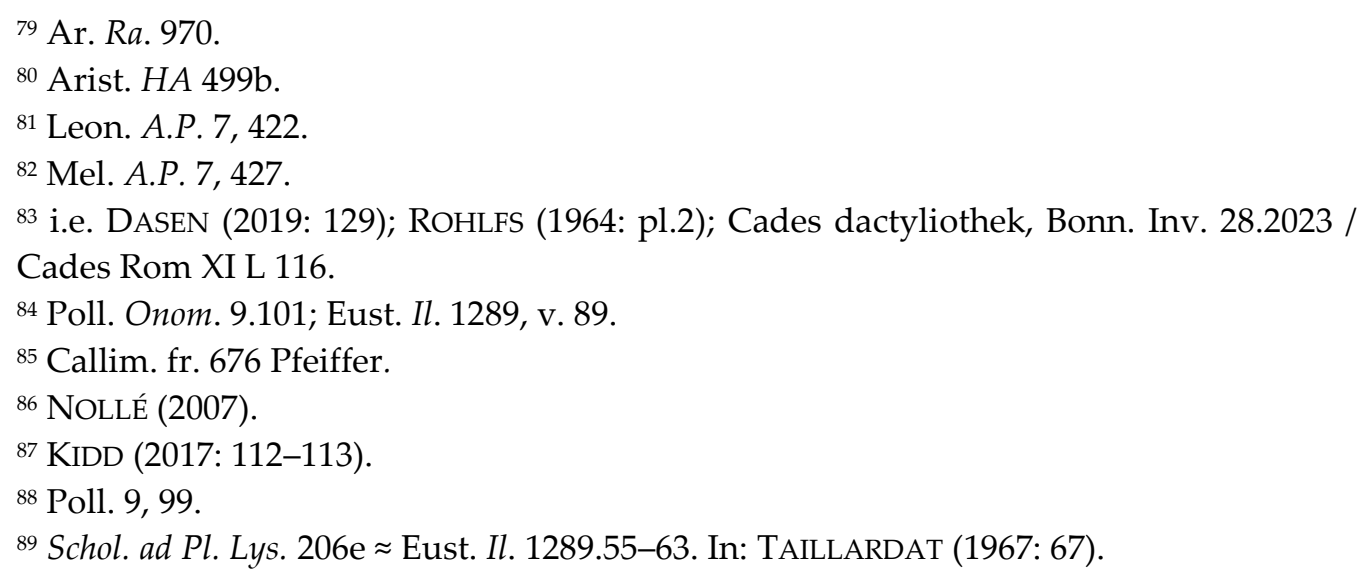


Kidd's thesis could be supported, however, by the fact that groups of five astragals have been discovered at different Hellenistic sites. ${ }^{91}$

In sum, a geo-historical analysis of the pieces of information related to this gaming tradition points to a complex stratification of heterogeneous practices. This mixture of recurring and varying elements reported by the classical authors, as well as the variation or permanence in the game's terminology, helps us to understand its cultural and historical complexity. It is probable that different variants emerged over the centuries or according to different regional uses which later converged into a standardized international gaming practice. Again, the historical reconstruction has been possible thanks to the study of ludonyms.

\section{Talannu and tali: a possible enigmatic connection}

The Roman game of tali is clearly connected with the Greek tradition, as shown by the convergence in the rules and ludonyms referred to it.

The exception is the name of the game, which does not appear to be linked to a Greek tradition: the word talus existed previously in Latin, probably already indicating the anklebone.

In the $19^{\text {th }}$ century it was considered etymologically related to the term tolus, as a derivation from tax-lus, ${ }^{92}$ which has also been connected to the term taxillus as a diminutive (which occurs, but with no clear meaning and not directly related to a gaming practice, in Cicero)..$^{93}$

More recently this interpretation has been dismissed and instead the etymology of talus is considered unknown. ${ }^{94}$

It is quite interesting to see how both the Latin word talus and the Akkadian talannu which indicate the knucklebone (one certainly and the other hypothetically), share the same root tal-.

Concerning this fact, Irving Finkel suggested that: 'Perhaps then the latin tālus should be grouped with the suggestive second- and first-

\footnotetext{
90 About this proverb and its connection with Stesichorus: Phot. Lex. ( $\pi 168$ Theodoridis) $=$ Sud. $\pi 225$ (4, 23 Adler) = Apostol. 13, 93 (2, 601 Leutsch-Schneidewin).

${ }^{91}$ PotTiER-ReinACH (1888: 215-217). KAOUKABANi (1973: pl. 2, 3). DusENBERY (1998: 199; 348-351). ERLICH (2017: 42).

92 LEWIS-SHORT (1879: 1835; 1844).

93 Cic. Or. 45, 153.

${ }^{94}$ GLARE (1982: 1902); ERNOUT-MEILLET (2001: 675).
} 
millennium cuneiform evidence and proposed as a loan from a Kulturwort for the knucklebone or astragals?' 95

Of course, finding strong evidence in support of the idea of a such linguistical stratification and linking the Semitic Akkadian of the $2^{\text {nd }}$ millennium BC with the Indo-European Latin of the $2^{\text {nd }}$ century BC is complex, especially because the Hittite and the Mycenaean idioms don't offer any possible and direct connection.

Anyway, there is another unexpected Greek term which is strongly related historically to knucklebone and could help with this speculation.

These bones seem to be connected with ponderal systems of the eastern Mediterranean since the Bronze Age. A find at Ugarit, ${ }^{96}$ one of the major ports during the Bronze Age, consists of a knucklebone hollowed and filled with lead, whose final weight was 280 grams, which exactly corresponded to 30 shekels. At that time, the shekel was a standard of weight that approximately corresponded to 9,4 modern day grams. This equivalence led some scholars to think that this object was used as a standard of weight. ${ }^{97}$

There is further evidence in the Aegean region that attests this local tradition of representing weights in the shape of astragals since the late Iron Age at least.

A bronze weight in the shape of a knucklebone melted in Miletus around 550-525 BC and offered to Apollo's oracle at Didima is stored at the Louvre. ${ }^{98}$ Originally it was part of a pair of identical objects, as stated by an inscription on it:

Those wonderful objects, produced with $1 / 10$ of the harvest, has been dedicate to Apollo by Aristolochos and Thrason. Pasikles, son of Kydimeneos, made them..$^{99}$

\footnotetext{
95 FINKEL (2007: 29).

96 SCHAEFFER (1962: 80-82).

${ }^{97}$ MiNNITI-PEYRONEL (2004: 14).

${ }_{98}$ Musée du Louvre, inv. sb2719.

${ }^{99} \mathrm{https} / / / \mathrm{www}$.louvre.fr/en/oeuvre-notices/weight-shape-knucklebone:

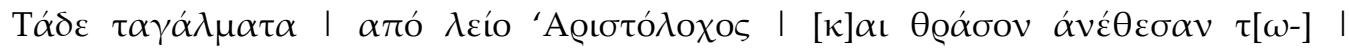

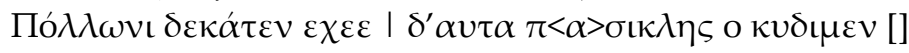


Herodotus comments on the importance of this oracle to which also Croesus offered valuable gifts in different passages, ${ }^{100}$ and tells us about its conquest and sack by the Persians occurring during the suppression of the Aristagoras' revolt of $494-493$ BC. ${ }^{101}$

This item was excavated in Susa, ${ }^{102}$ the Elamite capital, where it was found together with a similar object: a bronze weight of Mesopotamian production in the shape of a lion, ${ }^{103}$ now also at the Louvre. ${ }^{104}$

The peculiarity of these objects is that they represent two standards of weight in use in the Achaemenid Empire, the Babylonian and the Aegean one, and were probably used to compare these two systems.

The bronze astragals weigh $93 \mathrm{~kg}$, corresponding to 220 obols or 6,645 staters of Miletus, and the lion weighs $120 \mathrm{~kg}$. Since the Babylonian talents correspond to $30,4 \mathrm{~kg}$, the two objects weighed respectively 3 and 4 Babylonian talents.

So, the Ionian bronze astragal was preserved by the Persians because it was quite useful, since it corresponded to one of the few measures in which the Ionian and the Babylonian scales of weight, mathematically, were easily comparable.

In the Aegean region, the production of weights in the shape of astragals continued in the subsequent centuries. Different weights with a squared base and a half astragal in relief on one side have been found at the Agora of Athens. Its precise measure is marked on its base: $\sigma \tau \alpha \tau \eta \dot{\varrho}$ (statér), which correspond to $795 \mathrm{~g}$, and its authority: $\delta \varepsilon \mu o ́ \sigma ı v ~(D e-$ mosion, or sometimes Demosion Athenaion). ${ }^{105}$

Bronze astragals have also been found at Imera, in Sicily, which corresponded to a ponderal standard and, interestingly, were impressed

\footnotetext{
${ }^{100}$ Hdt. 1, 46; 1, 92; 5, 36.

${ }^{101}$ Hdt. 6, 18-19.

102 HAUSSOULlier (1905: 156-162); ANDRÉ-SALVINI-DESCAMPS-LEQUIME (2005).

103 The Assyrians used to shape their weights in form of lions and objects of this kind are found in the archaeological site since the first excavation of Layard at Nineveh. Some of them are now at the British Museum, inv. N91221.

${ }^{104}$ Musée du Louvre, inv. sb2718.

105 A sample: courtesy of the American School of Classical Studies at Athens: Agora Excavations, inv. B 495.
} 
with the symbol of the city, the same symbol that appeared also on Imerian coins. ${ }^{106}$

Coinage with decorations in the shape of astragals were issued also by other Greek cities, such as Athens in the $6^{\text {th }}$ century $\mathrm{BC}^{107}$ and it seems that these bones had a certain meaning in relation to the Aegean weight systems of the late Iron Age and early classic period.

This tradition continued during the period of Roman domination. A partially corrupted inscription dated to the time of Trajan has been found in Tegea which reports the dedication of a group of weights in the shape of astragals by Poplius Memmius Agatokles, when he ceased his activity as agoranomos (the public officer at the market who had to secure the respect of the standards):

Poplios Memmios Agatokles, after having served as Agoranomos consecrated the house of all the gods and the bronze weights inside of it ... and with ivory ... of one pound ... 50 ... Atalanta ... 25 of a pound ... [one] astragal [of] 1 pound, another ... of one pound ... $1 \ldots$ of ounce $\ldots 9 \ldots$ another $\ldots$ of one pound $\ldots 2 \ldots$ another $\ldots$ of one pound ... $4 \ldots$ Eros $^{108}$

Finally, impressive bronze weights in shape of astragals marked with silver Roman numbers are today at the Pera Museum of Istanbul, ${ }^{109}$ and Diodorus Siculus reported that the tin extracted in Britain in the $1^{\text {st }}$ century BC was melted in ingots shaped in the form of astragals.

Therefore, the connection between the Greeks' ponderal standards and knucklebones seems chronologically archaic, geographically wide-

\footnotetext{
106 ANZALONE (2009: 180, n. 41).

107 LANG-CROSBY (1964: BW1; LW 3-7; pl. 1-3).

108 IG V, 2 125:

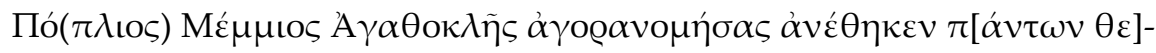

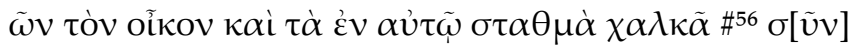

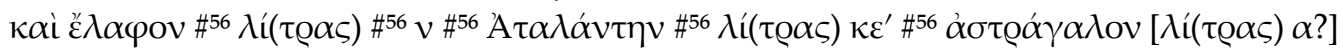

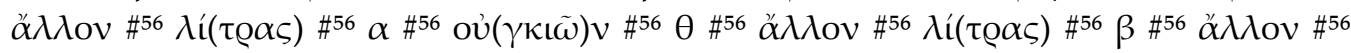
$\lambda \mathbf{i}(\tau \varrho \alpha \varsigma)[\# 56] \delta .[\# 56]{ }^{\prime} \mathrm{E} \omega \omega \tau \alpha[\# 56--]$.

${ }^{109}$ Istanbul, Pera Museum, Anatolian weight and measures collection. inv. PMA 6602 A-B-C.
} 
spread, and culturally persistent. All these aspects allow us to think that this is a legacy of the pre-classical period.

Interestingly, the highest ponderal unit in the Aegean system was

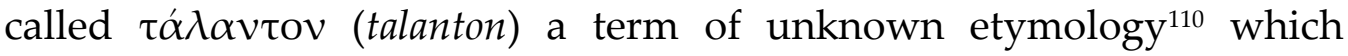
doesn't seem directly linked to any Mycenaean word. The closest term could be ta-ra-si-ja, ${ }^{111}$ which occurs in some tablets ${ }^{112}$ and referred to measures of bronze or wool which were "weighted and ready for the manufacturing". ${ }^{113}$

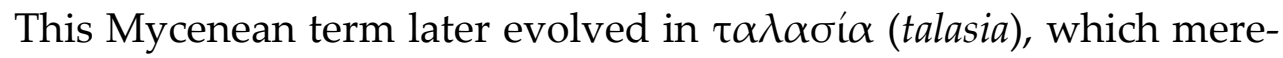
ly indicates the process of wool spinning and still preserves the root tal-.

In conclusion, this series of linguistic similarities do not constitute a strong and certain demonstration of the derivation of the word talus from some term of Near Eastern origins, but the connection of the term talus, talannu, talaton with the object, figure or concept of a knucklebone appears clearly and should be considered seriously.

\section{The loss of this historical, semantic and linguistical complexity}

A ludonym is a word functioning within a certain cultural system and does not correspond just to the name of a game, but conveys a complex of connotations of a cultural, emotional, social and interactive nature.

Playing at the astragals in Greece, as well as talis ludere in Rome, had specific implications. It was a game possibly also used for gambling, but also perceived as an archaic tradition and sometimes those gaming tools were used for divination, ${ }^{114}$ rituals, ${ }^{115}$ funerary purposes, ${ }^{116}$ or sacred mysteries. ${ }^{117}$

\footnotetext{
110 BEEKES (2010) didn't suggest any etymology for this word.

111 Mentioned in KN Lc 535, Py Jn 310, My Oe 110. I'm thankful for Rita Roberts for her help on this subject.

112 In the tablet PY Jn 310 the term a-ta-ra-si-jo (opposite of ta-ra-si-ja e-ko-te) is mentioned to indicate that a smith 'didn't produce a measure of bronze', in CHADWICK-BAUMBACH (1963: 247).

113 CHADWICK-BAUMBACH (1963: 247).

${ }^{114}$ For the use of astragals in divination: Paus. 7, 25, 10; Suet. Tib. 14; Schol. Pind. Pyth. 4, 337-338 (ed. Drachmann, pag. 143); IK Perge 205; KAIBEL (1878: 454-458, Epigrams 1038; 1039; 1040); NOLLÉ (2007).

115 Greek and Roman children of both genders, having reached majority, dedicate their toys at the temple: Anth. Pal. 6, 309; 6, 276; CIA II (766) / IG II, 2: 1533, 1.23-24, 32. And a huge quantity of astragals has been found inside the perimeter of cultic complex,
} 
Conversely, cubic dice were used merely for gaming and gambling purposes and even the ancient sources note the difference between these two games. As Martial wrote:

Never you left the innocent 'talus' for the die, and you gambled just few nuts. ${ }^{118}$

In a comic piece of writing by Herodas ( $3^{\text {rd }}$ century BC), a young schoolchild skips school to go to the gambling house and his mother decided to report everything to the teacher, underlining that her son passed from playing with astragals to gambling, eventually with dice:

Me unlucky, he sacked my house playing for money, and the astragals are no more enough for him! [...]

And the teacher answered the pupil directly:

[...] So is not enough for you to play with astragals of gazelle like those (his companions), but you enter the gambling house and gamble for money among the carriers!119

Playing dice or astragals were two different activities, similar in some aspects, but clearly distinct. In both cases the players cast a group of ob-

temple-caves, or under the foundation of shrines. The most evident case is the Corycian Cave, where has been found almost 23000 astragals: AMANDRY (1984: 347-380).

116 A great quantity of astragals has been found in graves. This use dated since the Bronze Age to the Roman era. Just few samples from the Near East: SPEISER (1935: 33); MUSCARELLA (1974: 80-81, n. 21); SCHAEFFER (1962: 80-82); GUY (1938: 77, pl. 115,11). From Greece: PAPAIKONOMOU (2013: 57); CARÈ (2013). From a Roman site: DE GROSSI MAZZORIN-MINNITI (2013). 117 The use of astragals in mysteries is reported mainly by the Christian authors of late antiquity: Clem. Al. Protr. 2, 11; Arn. Adv. Nat. 19, 4. A contemporary study about the use of astragals as a symbol of rebirth of near eastern origin and lately transmitted to the romans through the cult of the Dioscuri: LUSCHI (2008).

${ }_{118}$ Mart. 4, 66: Subposita est blando numquam tibi tessera talo, alea sed parcae sola fuere nuces...

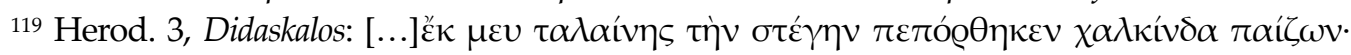

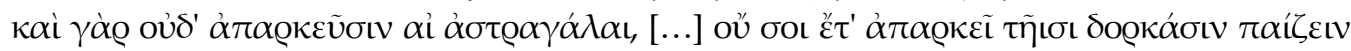

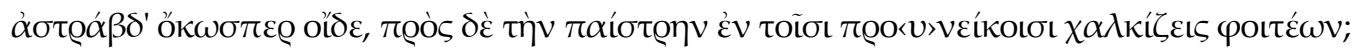

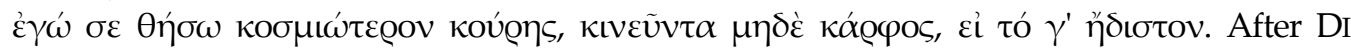

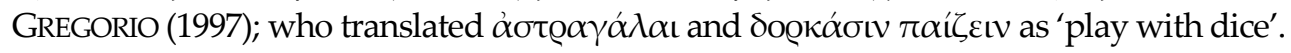


jects and maybe in some situations they could be interchangeable, but the authors of the classical period never created confusion between tesserae and tali, astragaloi and kuboi.

The throw of 'Venus', and the 'dog' were prerogatives of the astragals, like the absence of the scores 2 and 5 .

In the Etymologies of Isidore of Seville, written in Visigothic Iberia at the beginning of the $7^{\text {th }}$ century, we can note the first terminological confusion between dice and astragals. Isidore certainly studied the classics deeply and read about a game of chance in which the possible scores were just $1,3,4,6$, but in his time the game of astragals/tali was probably no longer in use in his region. So, he spontaneously updated what he found in the ancient texts relating it to his contemporary gaming practices. This terminological confusion didn't occur in the actual Greco-Byzantine sources, since the astragals remained in use in the eastern part of the Mediterranean, but Isidore describes the game using an improper terminology:

63 - About dice. Are said 'tesserae' since they are squared on all the sides. Others calls them 'lepusculi' (little hares) since after being tossed they run everywhere. Once, the dice were called also 'iacula' (darts), because were thrown.

65 - About the names of the dice. Among the ancients every throw got a name from its score, like 1, 3, 4, 6. Lately the denomination of the throws has changed, and the ace was called 'dog', the 3 'suppus' (from the Greek term 'uptios', which means supine), the 4 'planus' (from the Greek term 'pranes', which means prone). ${ }^{120}$

66 - About the throw of dice. The experts throw the dice in order to get what they want, like for example a 6, which gives them an advantage. On the other side, they try to avoid the ' $\operatorname{dog}^{\prime}$ since is unlucky: its score is indeed $1 .{ }^{121}$

\footnotetext{
120 This terminology makes reference to the shape of astragals, which presented a convex and a concave side which ideally looked like the two sides of a torso. About this terminology: Aristot. $H A$ 2, 1, 499b.

${ }^{121}$ Isid. Etym. 18, 63, 65-66: LXIII. De tesseris. Tesserae vocatae quia quadrae sunt ex omnibus partibus. Has alii lepusculos vocant, eo quod exiliendo discurrant. Olim autem tesserae iacula
} 
Isidore clearly reports a gaming practice related to the astragaloi/tali but makes repeated use of terms or expressions related to cubic dice, like $D e$ tesseris, Tesserae, De vocabolis tesserarum.

It is clear that he didn't have direct knowledge of the game of astragals and that this tradition, at his time, was already lost to some part of western Europe.

The decline of astragals and the rise of cubic dice is a long process that took place in late antiquity. The coexistence of the two traditions is attested by literary and material evidence for all classical antiquity, but the late imperial Latin sources, as distinct from Greek sources, mention almost exclusively the use of cubic dice or make reference to board games played with them.

The use of knucklebones as a game of chance disappeared from the western part of the Mediterranean and their literary presence largely passed unnoticed. In some regions they were in use as toys until the $19^{\text {th }}$ century and in certain regions of Italy they were still very popular as a game of aim and manual skill until the 1960s, but with the end of antiquity they lost all their symbolic value and their cultural complexity.

Since the Renaissance, the same issue affected the European philologists, who were unaware of this particular use of astragals and frequently interpreted the Latin word tali as a synonym of tesserae.

Curiously, this is probably because in the classical sources tali appears more prominently, hence Renaissance authors started to privilege it above the more correct tesserae.

When Plautus, Cicero, Ovid, Horace and Martial wrote talus or tali, they were clearly making reference to the game of knucklebones, but for centuries those passages have been considered as mentions of dice.

An interesting example of this misunderstanding is in the Christian treaty of Archelaus of Carcara, bishop of Carrhae in the $4^{\text {th }}$ century, known by its Latin title, Acta disputationis Archelai cum Manete:

appellabantur, a iaciendo; LXV. De vocabolis tesserarum. Iactus quisque apud lusores veteres a numero vocabatur, ut unio, trinio, quaternio, senio. Postea appellatio singulorum mutata est, et unionem canem, trinionem suppum, quaternionem planum vocabant; LXVI. De iactu tesserarum. Iactus tesserarum ita a peritis aleatoribus conponitur ut adferat quod voluerit, utputa senionem, qui eis in iactu bonum adfert. Vitant autem canem quia damnosus est; unum enim significat. 
The son of the king felt sick and since the king wished him to be healed, published an edict offering a great reward to the one who would have been able to heal him. So, this one (referred to Mani, the founder of Manicheism) just like the 'cibum', which is another way to call the ones that play at 'tali'/dice appeared personally in front of the king saying that he could heal the child. When the king heard it, welcoming him obsequiously kept him in his favor. ${ }^{122}$

The ludonym in this text shows an interesting historical and linguistic stratification. Everything probably occurred because of a series of human errors and causalities which created a certain confusion, but which is very indicative of a process of re-signification.

Probably Archelaus originally wrote in Syriac ${ }^{123}$ and later his writings were translated into Greek, ${ }^{124}$ and afterwards into Latin. Over the centuries, the copyists would have missed the meaning of this expression and stratified a series of mistakes, probably starting from copying a Greek word without translating it.

This obscure expression must have been copied incorrectly, since the word 'cibum' has no meaning. In this error we can clearly detect a corruption of the Greek word $\kappa v ́ \beta O s$ and the original meaning of the

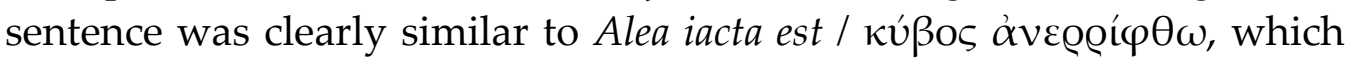
was quite a common locution in the Greek part of the Empire. ${ }^{125}$

\footnotetext{
${ }_{122}$ Archelaus, Acta disputationis Archelai cum Manete 53: [...] regis filius egritudine quadam arreptus est, quem rex curari desiderans, edictum proposuit in vita, si quis eum curare possit, accipere praemium, multo proposito. Tum iste, sicut illi, qui 'cibum', quod nomen est tale eludere solent, praesentiam suam Manes exhibet apud regem, dicens se esse puerum curaturum, quae cum audisset rex, suscepit eum cum obsequio, ac libenter habuit.

${ }^{123}$ About this cultural stratification and about Archelaus: entry Archelao di Carcara in PRINZIVALLI (1983: 317).

${ }^{124}$ Indeed, some fragments of this treaty written in Greek are quoted by Epiphanius of Salamis, Against Heresies, 66, 6-7; 25-31.

125 Many literary passages report the use of this locution or similar: Ar. Fr. 929K.-A; Aesch. Ag. 32-33; Pl. Leg. 12, 968e-969a; Plut. Mor. Quomodo adulator ab amico internoscatur 70c-d; Plut. Mor. De exil. 606b-c; Men. Fr. 64 K.-A. in Ath. 13, 8; Chariton of Aphrodisias, Callirhoe 1, 7, 1; App. B. Civ. 2, 35; Plut. Mor. Regum et imperatorum apophthegmata 206c; Plut. Caes. 32, 6; Plut. Pom. 60, 2, 9; Plut. Cor. 3, 1; Plut. Fab. 14, 1; Plut. Arat. 29, 5 (referred to astragals); Dio.

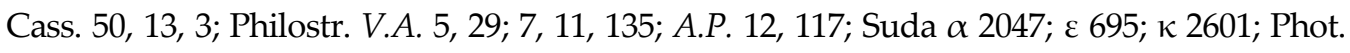
Lex. $\alpha$ 1639; Io. Chrys. Sermo cum presbyter fuit ordinatu, 20 (ed. J. P. MiGNE, P.G. 48, 694).
} 
To explain this intricate passage, some philologists who mastered it fortunately wrote an explanation, like an intertextual footnote, which would have been useless for an ancient Greek reader but is extremely useful for us: "cibum, quod nomen est tale eludere solent", in which eludere issued by another distraction of a copyist who probably misread talis ludere.

Lorenzo Zaccagni edited this text in 1698, copying it from a manuscript which was corrupted exactly in relaying this line, and he marked in his footnote: "locus valde corruptus" and that "forte lege(n)dum" the sentence could have been restored as: "qui cybum, quod nome est tali, ludere". ${ }^{126}$

The intricate history of this text clearly shows how the semantic overlap of the ludonyms related to astragals and dice remained unnoticed through the centuries.

Some other intellectuals of the Renaissance remarked on the difference between dice and tali but didn't manage to broadly influence the humanists and philologists. One of them was Gerolamo Cardano, who treats dice and tali separately, but his text, written around 1560, was published almost a century later and since it was conceived as a manual for gamblers, it did not influence the philological debate. ${ }^{127}$

This diversity began to be seriously considered as philologically relevant only in the $18^{\text {th }}$ century thanks to the pervasive references to astragals in Greek literature. In 1794 Monaldini glossed a passage of Apollonius of Rhodes $^{128}$ in which Ganymede and Eros play at knucklebones:

the confusion, which is huge among the antiquarians (classicists), about the ancient games of the Tessere, dice, tali, or aliossi ('a li ossi', lit. 'at the bones'), \&c. comes from confusing the moments with the instruments of games. The one which is mentioned here is the game of the 'aliossi', or 'tali', which is surely the most ancient, since is the simplest and is given by the nature of those small bones, that the anatomists observed in some quadrupeds and that finish the tibia in proximity with the articulation of the ankle: bones which the Greek called $\alpha \sigma \tau \varrho \alpha ́ \gamma \alpha \lambda$ ot. The Latins 'Tali' and 'talloni' the Italians.

\footnotetext{
126 ZACCAGNI (1698: 98).

127 CARDANO (1663).

${ }^{128}$ Ap. Rhod. Argon. 3, 112b-130; 154-155.
} 
At image of these bones has been lately shaped the 'tessere', dice, cubes, and all the other instruments that, with a variety of rules, formed the variety of those games which has been lately comprised by the generic name of 'alea'. About the difference of the 'aliossi' which are here concerned, and the other playing instruments, dice, 'tessere', \&.c. and of all these games in general consult the Collection of Gronovio, the treaties of Giulio Cesare Bulenghero 'De ludis veterum'; by Gio. Meursio 'De Ludis Graecorum'; by Daniel Suterio 'De alea, et variis ludis'; by Andrea Senetlebio 'De Alea Veterum'; and finally by Celio Calcagnino 'De Talorum Ludis'. ${ }^{129}$

It is significant that Monaldini opened this comment about the game of astragals by talking about the confusion of the philologists about the meaning of the ludonyms attributed to dice and knucklebones.

Much progress has been made in the field of game studies, supporting the textual mentions with material proof and evidence, and reconstructing with an unexpected degree of precision some of those gaming practices since that time.

Unfortunately, these advances still have to penetrate stably and widely in the mindset of philologists and in Latin dictionaries, which still consider the word talus to refer to the game of dice.

It will definitely require an effort to abandon a centuries-old tradition in translating the classics, but it would be necessary to reconsider the meaning of the word talus, starting to evaluate it on a chronological

129 MONALDINI-GIUNCHI (1794: 181-182), comment at the verse 174: La confusione, che massima si trova fra gli antiquarj su gli antichi giuochi delle tessere, dadi, tali, od aliossi, $\mathcal{E}$ c. viene dal confondere $i$ tempi, e gl'istrumenti delli giuochi medesimi. Questo che qui si accenna, che è quello degli aliossi, o tali, è certo il più antico, perché il più semplice, e dato dalla natura medesima in quei piccoli ossi, che gli anatomici hanno osservato in alcuni quadrupedi terminare

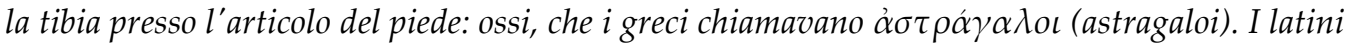
'tali', e 'talloni' gl'italiani. A somiglianza di questi ossi sono poi state dall'arte formate le tessere, $i$ dadi, $i$ cubi, e tutti quegli altri strumenti, che con variate regole han formato la varietà di quei giuochi, che sono poi stati compresi dal generico nome di 'alea'.

Su la differenza intanto degli astragali, o aliossi, de' quali qui si tratta, degli altri strumenti lusorj dadi, tessere Ec., e di tutti questi giuochi in generale, vedi nella Collezione del Gronovio i trattati di Giulio Cesare Bulenghero 'De ludis veterum'; di Gio. Meursio 'De Ludis Graecorum'; di Daniel Suterio 'De alea, et variis ludis'; di Andrea Senetlebio 'De Alea Veterum'; e finalmente di Celio Calcagnino 'De Talorum Ludis'. 
basis, since in antiquity it indicated exclusively the knucklebones and after the Middle Ages almost uniquely, but improperly, the cubic dice.

Restoring the original meaning of this word could help to rediscover the historical depth of this gaming practice and the process of stratification/migration of its ludonyms, as well as the relevance of playing activities in understanding antiquity and the historical processes that started, ended or straddled it.

\section{Bibliography}

AMANDRY 1984 P. AMANDRY: Os et coquilles. In: L'Antre corycien, 2, BCH suppl. 9, (1984) 347-380.

AND 1979 M. AND: Some Notes on Aspects and Functions of Turkish Folk Games. The Journal of American Folklore 92/363 (1979) 44-64.

ANDRÉ-SALVINI-DESCAMPS-LEQUIME 2005

B. ANDRÉ-SALVINI - S. DESCAMPS-LEQUIME: L'osselet de Suse: une prise de guerre antique. SMEA 47 (2005) 15-25.

ANDREESCU et al. 2006 R. R. ANDREESCU et al.: Magura, com. Magura, jud. Teleorman. Punct: Buduiasca, TELEOR 003. Cronica Cercetarilor Arheologice din România, Campania 2005, Bucarest 2006, 216-218.

ANNUS-SARV 2015 A. ANNUS - M. SARV: The Ball Game Motif in the Gilgamesh Tradition and International Folklore. In: R. Rollinger, E. van Dongen (ed.): Mesopotamia in the Ancient World: Impact, Continuities, Parallels, proceedings of the seventh symposium of the Melammu project, series Melammu Symposia, vol. 7 (2015) 285-296.

ANZALONE 2009 R. M. ANZALONE: Un astragalo di bronzo inedito da Himera. In: F. Camia - S. Privitera (ed.): Obeloi, Contatti, scambi e valori nel Mediterraneo antico, Studi offerti a Nicola Parise, series Fondazione Paestum Tekmeria, 11. Scuola archeologica italiana di Atene, 2009, 175-193.

BAGLIONE 1989-1990 M. P. BAGLIONE: Considerazioni sui santuari di Pyrgi e di VeioPortonaccio. Scienze dell' antichità 3-4 (1989-1990) 651-668.

BASS 1986 G.F. BASs: A Bronze Age Shipwreck at Ulu Burun (Kaş): 1984 Campaign. AJA 90/3 (1986) 269-296.

BECQ DE FOUQUIÈRES 1869

L. BECQ DE FOUQUIÈRES: Les jeux des anciens: leur description, leur origine, leurs rapports avec la religion, l'histoire, les armes et leur moeurs, Paris 1869.

BEEKES 2010 R. BEEKES: Etymological Dictionary of Greek. Leiden-Boston 2010.

BELDIMAN-SZTANCS 2010

C. BELDIMAN - D.M. SZTANCS: Date asupra industriei materiilor dure animale apartinând culturii Cucuteni-Ari- usd descoperită $\hat{\imath}$ 
asezarea de la Păuleni-Ciuc - "Dâmbul Cetătii", jud. Harghita. Angustia 14 (2010) 141-164.

BERCIU 1956 D. BERCIU: Cercetari si descoperiri în regiunea Bucuresti. Materiale si Cercetari Arheologice II (1956) 493-562.

BLEGEN-RAUSON 1966 C.W. BLEGEN - M. RAUSON: The palace of Nestor at Pylos, in Western Messenia. The buildings and their contexts, vol. I, part I: Text. Princeton 1966.

BONI 1899

G. BONI: Nuove scoperte nella città e nel suburbio. NSA (1899) 128-130.

CARÈ 2013

B. CARÈ: Knucklebones from the Greek Necropolis of Locri Epizefiri, Southern Italy. Typological and Functional Analysis. In: F. Lang (ed.): The Sound of Bones, ARCHAEOPlus. Schriften zur Archäologie und Archäometrie an der Paris Lodron-Universität Salzburg, 5 (2013) 87-99.

CARDANO 1663 G. CARDANO: Liber de ludo aleae. Lyon 1663.

Castellino 1977 G. R. CASTEllino: Testi Sumeri e Accadic. Turin 1977.

CAVRUC $2005 \quad$ V. CAVRUC: Some Eneolithic and Bronze Age funeral evidence on the salt exchange routs in Southeast Transylvania. Mousaios 10 (2005) 325-351.

CHADWICK-BAUMBACH 1963

J. CHADWICK - L. BAUMBACH: The Mycenaean Greek Vocabulary. Glotta 41, n³/4 (1963) 157-271.

CHOKHADZHIEV-CHOKHADZHIEV 2005

A. CHOKHADZHIEV - S. CHOKHADZHIEV: Some results of the investigations of Hotnitsa tell in 2001. L. Nikolova - J. Fritz - J. Higgins (ed.): Prehistoric Archaeology \& Anthropological Theory and Education, Reports of Prehistoric Research Projects 6-7. Salt Lake City 2005, 9-12.

CHOKHADZIEV 2009 A. CHOKHADZIEV: The Hotnitsa tell - 50 years later. Eight years of new excavations - some results and perspectives. F. Drasovean - D. L. Ciobotaru - M. Maddison (ed.): Ten years after: the Neolithic of the Balkans, as uncovered by the last decade of research, Bibliotheca Historica et Archaeologica Banatica XLIX, Timisoara 2009, 67-84.

CRIST-DE VOOGT-DUNN-VATURI 2016

W. CRIST - A. DE VOOGT - A.E. Dunn-VAturi: Facilitating Interaction: Board Games as Social Lubricants in the Ancient Near East. OJA 35/2 (2016) 179-196.

CRIST-DUNN-VATURI-DE VOOGT 2016

W. CRIST - A.E. Dunn-VATURI - A. De VoOgT: Ancient Egyptians at play. New York 2016.

CUllHed 2016 E. CUlLHED (ed.): Eustathios of Thessalonike, Commentary on Homer's Odyssey, Uppsala 2016.

D.G. HOGART 1908 D. G. HogART: Excavations at Ephesus, the Archaic Artemisia, vol. 2, London 1908.

DASEN 2019

V. DASEN (ed.): Ludique, jouer dans l'antiquité, Lyon 2019. 
DE GROSSI MAZZORIN-MiNNITI 2013

J. DE GROSSI MAZZORIN - C. MinNiti: Ancient Use of the knucklebone for rituals and gaming piece. Anthropozoologica 48/2 (2013) 371-380.

DE NAVARRO 1925 J. M. DE NAVARRO: Prehistoric Routes between Northern Europe and Italy Defined by the Amber Trade. GJ 66, N6 (1925) 481-503.

DUNN-VATURI 2012 A. E. DUNN-VATURI: Jeu de 20 cases, pions, osselets. In: I. Bardiès-Fronty - A. E. Dunn-Vaturi (ed.): Art du jeu, jeu dans l'art, de Babylone à l'Occident médiéval. Réunion des musées nationaux, 57, Paris 2012.

DUSENBERy 1998 E. B. DusEnBERY: Samothrace, Vol. 2: The Nekropoleis and Catalogue of Burials, ed. Princeton University Press, 1998.

ERLICH 2017

A. ERLICH: Happily Ever After? A Hellenistic Hoard from Tel Kedesh in Israel, in American Journal of Archaeology, vol. 121, n 1, 2017. 39-59.

ERnOUt-MeIllet2001 A. ERnOut - A. MeILlet: Dictionnaire Etymologique De La Langue Latine, IV edition, Paris 2001.

FALKENSTEIN 1952 A. FALKENSTEIN: Inannas Erhöhung. Bibliotheca Orientalis 9 (1952) 88-92.

FINKEL 1993

I. FINKEL: Board games and fortune telling. A case from antiquity. A. De Voogt (ed.): New Approaches to Board Games Research: II AS Working Papers series vol. 3. Leiden 1993, 64-72.

FINKEL 2007 I. L. FINKEL: On the Rules for the Royal Game of Ur. I. L. Finkel (ed.): Ancient Board Games in perspective. London 2007, 16-32.

FRANKFORT-PENDELBURY 1933

H. FrAnKFort - J. Pendelbury: The city of Akhenaten (part 2). London 1933.

GJERSTAD1960 E. GJERSTAD: Early Rome, vol. III, Lund 1960.

Glare 1982 P. G. W. GLARE: Oxford Latin Dictionary. Oxford 1982.

GUY 1938

P. L. O. GUY: Megiddo tombs. OIP 33 (1938).

HADDOW 2015

S. D. HADDOW (ed.): Çatalhöyük 2015 Archive Report by members of the Çatalhöyük Research Project (2015). Online PDF on the official website of the Çatalhöyük excavations: https://www.catalhoyuk.com/sites/default/files/media/pdf/Archi ve_Report_2015.pdf

Haussoullier 1905 B. Haussoullier: Offrande à Apollon Didyméen. In: E. Bertrand (ed.) Mission de la Délégation en Perse, VII, 1905, 156-162.

HRUŠKA 1960 B. HRUŠKA: Das Spätbabylonische Lehrgedicht "Inannas Erhöhung". Archiv Orientalni 37 (1960) 473-522.

HUNTER 1983 R. HunTER: Eubulus: The Fragments. Cambridge 1983.

KAIBEL 1878 G. KAIBEL (ed.): Epigrammata Graeca. 1878.

KAVRuK et al. 2010 V. KAVRUK et al.: Soimeni - Ciomortan, com. Pauleni Ciuc, jud. Harghita, Punct: Dâmbul Cetatii. Cronica Cercetarilor arheologice din România. Campania 2009, cIMeC - Institutul de Memorie Culturala (2010) 180-186. 
KAVRUK et al.2013 V. KAVRUK et al.: Soimeni (Ciomortan), com. Pauleni Ciuc, jud. Harghita, Punct: Dâmbul Cetatii. Cronica Cercetarilor arheologice din România. Campania 2012, cIMeC - Institutul de Memorie Culturala (2013) 124-128.

KIDD 2017 S. KIDD: Greek dicing, astragaloi and the 'Euripides' throw, Journal of Hellenic Studies 137 (2017) 112-118.

KNUDZTON 1915 J.A. KNUDZTON: Die El Amarna Tafeln, I. VorderasiaJsche Bibliotek 2/I, Leipzig 1915.

KOGĂLNICEANU-ILIE-MĂRGĂRIT-SIMALCSIK 2014

R. KOGĂLNICEANU - A. ILIE - M. MĂRGĂRIT - A. SIMALCSIK: A hoard of astragals discovered in the Copper Age settlement at Iepureşti, Giurgiu County, Romania. Documenta Praehistorica 41 (2014) 283-304.

Kogan 2011 L. KogAn: Proto-Semitic Lexicon. The Semitic Languages. An International Handbook. Berlin 2011. 179-258.

KAOUKABANI 1973 B. KAOUKABANI: Rapport préliminaire sur les fouilles de Kharayeb 1969-1970. BMusBeyr, n²6, 1973. 41-59.

KÜCHELMANN 2017/2018

H. C. KÜCHELMANN: Why 7? - Rules and Exceptions in the Numbering of Dice. Palaeohistoria, acta ed communicationes instituti archaeologici universitatis groninganae 59/60 (2017/2018) 109-133.

LAMBERT 1971 W.G. LAMBERT: Critical Notes on Recent Publications, II. L'Exaltation d'Ishtar. OR 40 (1971) 91-95.

LANDSBERGER 1960 B. LANDSBERGER: Einige unerkannt gebliebene oder verkannte Nomina des Akkadischen. Wiener Zeitschrift für die Kunde des Morgenlandes 56 (1960) 109-129.

LANG-Crosby 1964 M. LANG - M. Crosby: The Athenian Agora, vol. X. Weights, Measures and Tokens. Princeton 1964.

LANGDON 1915 S. LANGDON: A bilingual tablet from Erech of the first century BC. Revue d'assyriologie et d'archéologie orientale. 12/2 (1915) 73-84.

LANGDON 1919 S. LANGDON: A Bilingual Tablet from Erech. RA 12 (1919) 73-84.

LANGDON 1923 S. LANGDON: Hymn in Paragraphs as the Belit of Nippur. AfK 1 (1923).

LANSING 1917 A. LANSING: The Egyptian expedition 1915-1916. BMM 12/5 (1917) 1-31.

LEWIS-SHORT 1879 C. T. LEWIS - C. SHORT: A Latin dictionary. Oxford 1879.

LORENZ 2003 D. LORENZ: Zur Vormund Frühgeschichte des Tierser Tales. Der Schlern 77, vol.6 (2003) 4-23.

LUSCHI 2008 L. LUSCHI: L'ariete dei "Manlii": note su una "tessera hospitalis" dal Fucino. In: SCO 54 (2008) 137-186.

MarcKeVich 1981 V. I. MARCKeVICH: Late-Tripolian Tribes of Northern Moldavia. Ştiinţa. Kishinev 1981.

MARCONI-TECCHIATI 2006

S. MARCONI - U. TECCHIATI: La fauna del villaggio della prima età del ferro del Thalerbühel di Tires (BZ), Economia, uso del territorio e strategie insediati tra II e I millennio a.C. In: (a cura di) A. Curci, Atti 
del convegno di archeozoologia "Animali tra uomini e dei: archeolzoologia del mondo preromano". Monterenzio 2006, 11-26.

MiNNITI-PEYRONEL 2004

C. MinNITI - L. PEYRONEL: Symbolic or functional astragali from Tell Mardikh-Ebla (Siria). Archeofauna 14 (2004) 7-26.

MONAH et al. 2003 D. MONAH et al.: Poduri - Dealul Ghindaru. O Troie in Subcarpatii Moldovei. Series Bibliotheca Memoriae Antiquitatis XIII (2003).

MONALDINI-GIUNCHI 1794

V. MONALDINI - P. GIUNCHI: Commento All'argonautica di Apollonio Rodio tradotta ed illustrata, vol. II, Rome 1794.

Muscarella 1974 O. W. Muscarella: The Iron Age at Dinkha Tepe, Iran. MMJ 9 (1974) 35-90.

NICA-ZORZOLIU-FÂNTÂNEANU-TANASESCU 1977

M. NiCA - T. ZORZOLIU - C. FÂNTÂNEANU - B. TANASESCU: Cercet ări arheologice în tell-ul gumelniteano-salcutean de la Draganesti-Olt, punctul "Corboaica". Campania anului 1955. Cercetari Arheologice în Aria Nord-Traca II (1977) 9-19.

NOLLÉ 2007 J. NOLLÉ: Kleinasiatische Losorakel. Astragal und Alphabetchresmologien der hochkaiserzeitlichen Orakelrenaissance. series Vestigia, Beiträge zur alten Geschichte 57, 2007.

PAPAIKONOMOU 2013 I. D. PAPAIKONOMOU: L'astragale en contexte funéraire, Amphipolis, Thasos et Abdère, in Archéothéma. 31 (2013) 57.

PICCIONE 2007 P. PICCIONE: The Egyptian game of Senet and the migration of the soul. In: I. Finkel (ed.): Ancient Board games in perspective. London 2007, 54-63.

POPLIN 2001 F. POPLIN: Reflexions sur l'astragale d'or de Varna, les pieds fourchus et la métallisation de l'animal. J. P. Mohen (ed.): Découverte du metal. Paris 2001, 31-42.

PrinZIVALLi 1983 E. PRINZIVALLI (ed.): Dizionario patristico e di antichità cristiane, vol. I, Casale Monferrato 1983.

POTTIER-REINACH 1888 E. POTTIER - S. REINACH: La nécropole de Myrina. ed. École Française d'Athènes. Paris 1888.

Pusch 1979 E. B. PusCH: Das Senet-Brettspiel im Alten Ägypten. Munich 1979.

QuiBel 1909 J. E. QuiBELL: Excavations at Saqqara 1907-1908. Cairo 1909.

RIEDEL-TECCHIATI 2001 A. RIEDEL - U. TECCHIATI: Gli astragali dei corredi tombali della Necropoli della prima età del ferro di Colombara di Gazzo Veronese. Padusa 37 (2001) 149-151.

RIEDEL-TECCHIATI 2005 A. RIEDEL - U. TECCHIATI: I resti animali dell'ustrinum di Bronzo finale di Vàdena (Pfatter) presso Bolzano (scavi 1997-1998). Revue de Paléobiologie (special issue) 10 (2005) 121-128.

ROHLFS 1964 G. ROHLFS: L'antico Giuoco degli astragali. Lares 30, 1/2 (1964) 1-13.

SCHAEFFER 1962 C.F.A. SCHAEFFER: Ugaritica IV. Paris 1962.

SIDÉRA-VORNICU TERNA 2016

I. SIDÉRA - A. VORNICU TERNA: The archaeology of games. Playing 
with knucklebones in the early chalcolithic of the Balkans. K. Bacvarov - R. Gleser (ed): Southeast Europe and Anatolia in prehistory, essays in honor of Vassil Nikolov on his $65^{\text {th }}$ anniversary, Universitätsforschungen zur prähistorischen Archäologie, Band 293. Bonn 2016, 379-388.

SPEISER 1935

E. SPEISER: Excavations at Tepe Gawra. Philadelphia 1935.

TAILLARDAT 1967

T. TAILlardat: Suetonius: Peri blasphēmiōn, Peri paidiōn. Paris 1967.

TAIT 1982

W .J. TAIT: Game-boxes and accessories from the tomb of Tutankhamun. (Tutankhamun's tomb series VII). Oxford 1982.

TECCHIATI 2005 U. TECCHIATI: Osservazioni sui resti faunistici della necropoli protostorico di Ponte Nuovo di Gazzo Veronese. Notizie Archeologiche Bergomensi 13 (2005) 125-132.

THOMSON-FORESTER 1909

A. THOMSON - T. FORESTER (ed.): The Lives of the Twelve Caesars, to which are added his Lives of the Grammarians, Rhetoricians, and Poets. The translation of Alexander Thomson, M.D. Revised by T. Forester. London 1909.

THUREAU-DANGIN 1914

F. THUREAU-DANGIN: L'Exaltation d'Ištar. RA 11 (1914) 141-158.

URSULESCU-BOGHIAN 1996

N. URSULESCU - D. BOGHIAN: Principalele rezultate ale cercetarilor arheologice din asezarea precucuteniana de la Târgu Frumos (jud. Iasi). Codrul Cosminului 2, n²12 (1996) 38-72.

VERMAAK $2011 \quad$ P. S. VERMAAK: A new interpretation of the playing objects in the Gilgamesh epic. Journal for Semitics 20/1 (2011) 109-138.

VoINeA-NeAgu 2009 V. VOINEA - G. NeAgU: Archaeological Research at Hamangia III Settlement from Cheia (2004-2008). Pontica 41 (2009) 9-34.

ZACCAGNi 1698 L. ZACCAGNi: Collectanea Monumentorum Veterum Ecclesiae Graecae, ac Latinae quae hactenus in Vaticana Bibliotheca deliturerunt, vol. I, 1698.

ZGOLL 1997

A. ZGOLL: Der Rechtsfall der En-hedu-Ana im Lied nin-me-šara. AOAT 247 (1997). 